\title{
Effect Of Teacher Training And Level Of Education On The Quality Of Learning
}

\author{
Harsono ${ }^{1}$, Sofyan Anif ${ }^{2}$, Muhammad Fahmi Johan Syah $^{3}$, Nien Islami Yantika ${ }^{4}$ \\ $\left\{\right.$ har152@ums.ac.id ${ }^{1}$, sa163@ums.ac.id ${ }^{2}$, mfj120@ums.ac.id ${ }^{3}$, Nien.Islami@gmial.com $\left.{ }^{4}\right\}$
}

${ }_{1,2,3,4}$ Universitas Muhamamdiyah Surakarta

\begin{abstract}
Private school teachers' lack of enthusiasm to attend and participate in professional development trainings has motivated the study to investigate whether teacher training and education has positive impact on learning quality improvement. This study aims at describing the effect of teacher training and education on learning quality. It is designed as a quantitative study carried out in a private senior high school with questionnaire as research instrument. Data analysis was performed with statistical instruments. The present study found the low participation of private school teachers in attending professional development training and teacher education. In fact, some teachers have never joined such trainings. The finding also reveals teacher training and education have a positive impact on improving the quality of learning activities. Nevertheless, this study is limited on a small population since it was carried out only in one private school.
\end{abstract}

Keyword: teacher training, level of education, quality of learning

\section{Introduction}

Pursuing an education is one of God's commands as well as a manifestation of human worship [1] and also teacher has the prominent role in the education process [2]. Education is a conscious effort to prepare learners by guiding, teaching, and/or training them for their role in the future [3]. It is an endeavor to guide learners toward moral knowledge and moral actions [1]. Briefly, it is an endless divine duty for human to gain knowledge about the entire Earth and Sky through the process of guidance, teaching and practice in order to understand moral values and more essentially, to speak and behave according to those values.

Education is a noun, while the verb is to educate - which is the task that must be carried out by an educator. The task of educating children is primarily conducted by parents-mother [4] and community in particular, and it is the duty and responsibility of the State in general-in this context, religious figures [5] and/or educators. Law No. 14 of 2005 on Article 10, paragraph 1 concerning Teachers and Lecturers, states that as professional educators, Teachers have the main task of educating, teaching, guiding, directing, coaching, assessing, and evaluating learners in formal early childhood education, primary and secondary education.

Furthermore, Hayes, Mills, Christie and Lingard suggested that the main tasks of teachers are to educate, continuously improve student achievement, and ensure the quality of education as well as leaning outcomes [6]. Consequently, teachers are required to have the competence and skills [3], which can be developed through a learning process since they are the main source of student's learning activities. Primarily, the indicators of professional teachers include: 1) mastering the knowledge of the subject being taught, namely students; 2) having class management skills; 3) continuously improving personal competence and skills through independent learning or courses; 4) conducting research to produce new knowledge; 5) being aware of student progress [7]. In this era, teachers are encouraged to do a deep learning in the context of $21^{\text {st }}$ century learning [8]. 
One of the main concerns in Indonesia, however, is the low quality of national education-which is claimed to be lower than Vietnam's. As a result, teachers are often questioned regarding the poor quality of national education, since it is linked to teacher's lack of competence and skills[9]. They are deemed to neither sufficiently master the subjects nor being able to utilize and implement the basic principle of appropriate teaching [10](, hence their instructional strategies are poor [11] and exacerbated by the absence of principal's guidance, leading to teacher's full authority in carrying out a class [3]. The quality of learning is indicated from teacher quality standards thus the government has to continuously improving the quality of teachers. As the spearhead of the learning activities, teachers are required to improve the quality of learning and creativity, and to innovate as well. The role of the teacher as a professional educator is crucial, ranging from improving the quality of the learning process to determining the student achievement in the process.

The quality of learning can be interpreted as the linkage among teachers, students, material, learning environment and learning media to attain optimal learning processes based on a predetermined curriculum [12]. In this context, teachers must be able to bring changes to students [13], including the changes in their behavior [14]. Furthermore, the improvement of learning quality entails several matters, i.e., curriculum renewal, textbook development, advanced teaching methods, teacher education and material facilities from school, administration, interaction between school and communities, teacher quality and interrelated education development. One of the indicators of successful learning quality improvement is indicated by the teacher's ability in utilizing learning media, for instance attractive posters based on the subject matter for creating an effective learning [7].

Teachers are the key to improving the quality of education [4], one of which is in the classroom. Nevertheless, there are several factors that influence the quality of learning, including level of education, experience, job desk, employment status, work ethic, welfare and infrastructure [15]. In addition, learning innovation training and learning media preparation can also support the improvement of learning quality [16]. Some factors also affect professionalism of teachers, including level of education, training and equalization programs, upgrading program, good relationship among colleagues, collaboration and links, work ethic that prioritizes high-quality services to satisfy the customers, and adoption of innovations in the use of the latest communication and information technology [17].

One of the factors that affect the quality of learning is the teacher's capacity to improve the competence and skills through their participation in various trainings organized by schools and/or institutions. Such trainings include curriculum development training, learning media training, class management training, seminars, workshops and related activities. Through these activities, teachers will be able to develop their competence, skills, and attitudes in carrying out the learning process. In addition, teacher's level of education is related to the improvement of learning quality. It refers to the level of formal education that must be carried out by teacher candidates before entering the educational world. Law No. 14 of 2005 article 8 stipulates a teacher to have academic qualifications, competencies, educator certificates, physical and spiritual health, and the ability to realize the national education goals.

Despite of its significance, research on teacher training is relatively rare because it is probably a less interesting topic [18] but teacher training is always the key for the teacher professional development [19] and have impact in the future generation [20]. In the most current technology development, teacher training should adapt the teacher training by using technology to push the teacher competencies [21]. This government must provide the assessment for teacher competency comprehensively so that it can increase the teacher perception, in turn improve the quality of learning [22]. Furthermore, the classroom quality also affects the quality learning 
[23]. Even so, research on teacher training and education level is required for supporting government policy. Teacher training is estimated to affect the quality of learning since teachers can develop skills and competences, gain new insight bout knowledge, skills and attitudes in teaching. In addition, the level of teacher education is also estimated to have impact on the quality of learning. The higher the teacher's level of education, the higher the number of teacher's participation in relevant professional development trainings. As a result, there is a gradual process of improving the quality of learning.

Initially, a preliminary study was carried out in the field. It involved observations at the classroom and in-depth interview with teachers relating to the topic of the present study. The results of observation conducted in Class X Accounting 3 indicated that the strategies used by the teacher in delivering the material of Accounting for Service Company was less interesting. The students had off-topic conversation, and were daydreaming and inattentive during the class. Consequently, they had difficulty in understanding the material just explained by the teacher. Moreover, the learning environment was not conducive since some students brought snacks and drink in the classroom and the teacher neither provide nor relate the material with real life examples. The preliminary study also obtained the data from SMK Muhammadiyah 2 Klaten Utara in which there were 45 teachers with different educational backgrounds (S1 and S2) and participation in assorted trainings.

The objectives of the present study: (1) to determine the effect of teacher training on the quality of learning in SMK Muhammadiyah 2 Klaten Utara, (2) to determine the effect of teacher's level of education on the quality of learning in SMK Muhammadiyah 2 Klaten Utara, and (3) to determine the effect of teacher training and the level of education on the quality of learning in SMK Muhammadiyah 2 Klaten Utara.

The research hypotheses are: (1) teacher training has impact on the quality of learning, (2) the level of education has impact on the quality of learning, (3) teacher training and the level of education has impact on the quality of learning.

\section{Method}

The respondents are the entire population. In the present study, 45 teachers of SMK Muhammadiyah 2 Klaten Utara 2 became the subjects since this study included population research thus the total population were involved. The dependent variable is the quality of learning $(\mathrm{Y})$, while the independent variables are teacher training $\left(\mathrm{X}_{1}\right)$ and the level of education $\left(\mathrm{X}_{2}\right)$. These variables, typically, can be measured so that numbered data can be analyzed using statistical procedures [24]. Instruments for collecting data are questionnaires and documentation. Furthermore, the stages are: 1) preparing the questionnaire; 2) composing the questionnaire; and 3) determining the criteria of scoring. Testing the questionnaire uses reliability and validity tests. The technique for the pre-test consists of normality and linearity tests with a significance level of 0 , and multicollinearity measured by tolerance and variance inflation factors (VIF). Multiple linear regression analysis technique for data analysis is done using hypothesis test of T-test and F-test. Furthermore, the coefficient of determination is determined to predict the contribution of the independent variable to the dependent variable, as well as relative contributions and effective contributions. The present study is expected to obtain positive, valuable, and statistically accountable results without triggering any pointless argumentation.

\section{Results and Discussion}

The results of the pre-test or normality test were used to find out whether the data from the sample derived from the population was normally distributed or not. The data is normally 
distributed if the p-value is less than 0.05 . The data analysis indicated the residual of 0.965 , which is greater than the significance level of 0.05 , therefore it can be claimed that the data is normally distributed.

The second hypothesis test is the linearity test used to decide whether two or more variables have a linear relationship and whether the relationship is strong enough. The data have linear relationship if the $\mathrm{p}$-value is greater than 0.05 or at a significance level of 0.05 . The results of linearity test were as follows:

Table 1. The Results of Linearity Test

\begin{tabular}{lccl}
\hline \multicolumn{1}{c}{ Variable } & Sig & Std. Error & Description \\
\hline $\begin{array}{l}\text { The effect of teacher training on the } \\
\text { quality of learning }\end{array}$ & 0.592 & 0.05 & Linear \\
$\begin{array}{l}\text { The effect of the level of education on the } \\
\text { quality of learning }\end{array}$ & 0.083 & 0.05 & Linear \\
\hline
\end{tabular}

The third pre-test is multicollinearity test used to identify correlations between independent variables of two regression models. If the tolerance value is less than 0.1 and, simultaneously, the VIF value exceeds 10 , the multicollinearity is regarded problematic. In the present study, the results of the multicollinearity test were as follows:

Table 2. The Results of Multicollinearity Test

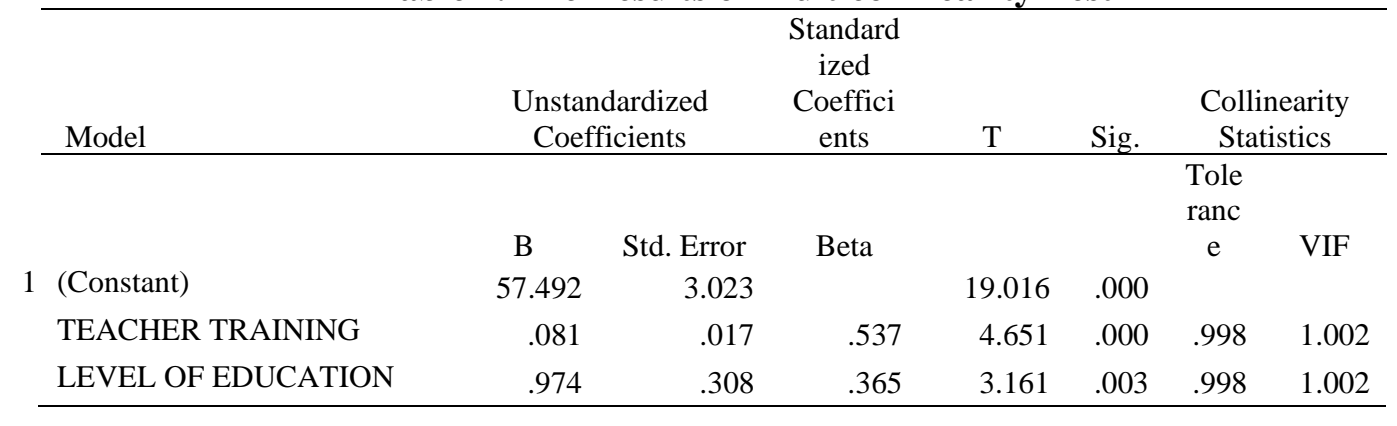

After the pre-tests have been conducted, hypothesis testing is carried out. The data are analyzed using multiple linear regression analysis.

Table 3. The Results of Multiple Linear Regression Analysis

\begin{tabular}{lccc}
\hline \multicolumn{1}{c}{ Variable } & $\begin{array}{c}\text { Regression } \\
\text { coefficient }\end{array}$ & $\mathrm{T}_{\text {value }}$ & Sig. \\
\hline Constant & 57.492 & & \\
Teacher Training & 0.081 & 4.651 & 0.000 \\
Level of Education & 0.974 & 3.161 & 0.003 \\
$\mathrm{~F}_{\text {value }}$ & 16.531 & & \\
$\mathrm{R}^{2}$ & 0.440 & & \\
\hline
\end{tabular}


After a multiple linear regression analysis was done, the hypotheses were tested using T-test and F-test. The first was used to determine the significance of the correlation between independent variables (teacher training and level of education) on the dependent variable (the quality of learning).

The results of $\mathrm{T}$-test for variable of teacher training $\left(\mathrm{X}_{1}\right)$ show that $\mathrm{t}_{\mathrm{value}}(4.651)$ is greater than $\mathrm{t}_{\text {table }}(2.018)$, therefore $\mathrm{H}_{0}$ is rejected. It implies that teacher training has impact on the quality of learning, proving the first hypothesis is true. Furthermore, the results of T-test for variable of the level of education $\left(\mathrm{X}_{2}\right)$ show that $t_{\text {value }}(3.161)$ is greater than $t_{\text {table }}(2.018)$, therefore $\mathrm{H}_{0}$ is rejected. It suggests the effect of the level of education on the quality of learning, proving the second hypothesis is true.

Subsequently, F-test was conducted to determine the significance of two variables of teacher training and the level of education in simultaneously affecting the dependent variable (the quality of learning). The results of $F$-test show that $F_{\text {value }}(16.531)$ is greater than $F_{\text {table }}(3.22)$, therefore $\mathrm{H}_{0}$ is rejected. It suggests that teacher training and the level of education simultaneously affects the quality of education, which implies the third hypothesis is true.

The coefficient of determination test is used to decide the magnitude of the effect of independent variable on dependent variable. Based on the data analysis, the coefficient of determination $\left(\mathrm{R}^{2}\right)$ was 0.440 . It indicates that the quality of learning is influenced by teacher training and the level of education, simultaneously, by $44 \%$. Moreover, the remaining $56 \%$ is influenced by other variables excluded from the present study. The relative contribution to teacher training variable was $29.70 \%$ while to the level of education was $70.30 \%$. Meanwhile, the effective contribution to teacher training was $13.07 \%$ and to the level of education was $30.93 \%$.

The effect of teacher training found in the present study is relevant to Fatah Syukur (2012: 90) whose study affirms the importance of teacher training to support teachers in understanding what and how professional teacher is, and improving their personality, individual performance, progress in career, effective behaviors, as well as competence and skills. Similarly, the present study reaffirms Fazalur Rahman (2011), who concluded that the programs of teacher training have positive impact on the quality of learning, emphasizing the importance of continuous training programs and the provision of broader opportunity for teachers to attend such programs due to its highly significant relationship to the improvement of learning activities and student performance.

In the context of the level of education, the result of the present study is relevant to Hasanah (2012: 52) in which the level of education is the benchmark to assess teacher's professionalism, in accordance with the provisions of the Law on Teacher and Lecturer. It also confirms the finding reported by Tri Nuruni (2014) which states that the level of education has a positive impact on the performance of teacher. Moreover, teachers must be in charge for subject areas based on their qualifications and academic background. Those graduates from faculty of history must teach history subjects, while those graduates from English department must teach English subjects, not vice versa. It is very influential on the performance and quality of students since teachers who deliver subjects without relevant educational background will hinder their students in understanding the subject. Briefly, the level of education is crucial on the quality of learning in the classroom.

Similarly, the findings of the resent study also reaffirm previous study carried out by Murniati (2016) concerning the main goal of teacher education and training, which is improve teacher's knowledge, skills, and motivation or attitudes/behaviors and to develop the competencies of participants regarding their job desks and relevant duties. The present study reinforces the more teachers and the more often they attend professional development programs, 
the better the quality of learning. As a result, students will have a better understanding and sharp insight to a knowledge, and eventually, they can attain more achievement and be naturally contented by the experiences with professional teachers.

In overall, the results show that by participating in training and education programs for teachers, they will be more professional and be able to improve the quality of learning. Ultimately, the high quality of learning will guide and assist students to learn optimally and perform learning activities effectively.

\section{Conclusion}

A study on the effect of teacher training and the level of education on the quality of learning has been conducted. Specifically, several points are concluded as follows:

a. Teachers with experiences in attending training programs have a better performance and, consequently, they are able to create or manage a conducive learning based on the need of the class. Moreover, professional development trainings support teachers to provide a constructive, acceptable environment for learning. As a result, the students will pay attention to the materials delivered by the teacher, instead of daydreaming, having offsubject conversation, or being busy with mobile phone.

b. That teachers who have experience in training tend to have good learning performance, in turn can create or organize learning that is appropriate to students' learning needs. Teachers who have experience in career coaching training tend to have quality learning that can be accepted by students, students are not sleepy in class, do not speak alone, do not play cell phones and concentrate on what is taught by their teacher.

c. The academic background that is linear to the subject area being taught by a teacher will improve the quality of learning and, eventually, will assist the student to have better performance. Briefly, the linearity between the academic background and the field of duty should be emphasized by policy/decision makers in assigning a teacher. They include the principal, the local office of education and culture, the provincial office of education and culture, and the ministry of education and culture. Private schools, particularly, should gain more attention instead of being neglected by the policy/decision makers.

d. The academic background and the attendance of professional training programs relevant to the field of duty simultaneously have a positive impact on the fluency of the teacher to carry out the task. Teachers with academic background linear to both the subject delivered to the class and training programs will be more prolific and effective in transferring the materials to students. Ultimately, the students are able to receive the lesson optimally.

\section{References}

[1] Ajat Sudrajat, "Mengapa Pendidikan Karakter?," J. Pendidik. Karakter, vol. 1, no. 1, pp. 47-58, 2011.

[2] E. Solak, "English Teacher Training Programs in Denmark, Sweden and Turkey," Procedia - Soc. Behav. Sci., vol. 232, no. April, pp. 439-443, 2016.

[3] E. Manik and K. Bustomi, "Budaya Organisasi Dan Motivasi Kerja Terhadap Kinerja Guru Pada Smp Negeri 3 Rancaekek,” J. Ekon. Bisnis Entrep., vol. 5, no. 2, pp. 97107, 2011.

[4] L. McDavid, A. E. Cox, and A. J. Amorose, “The relative roles of physical education teachers and parents in adolescents' leisure-time physical activity motivation and behavior," Psychol. Sport Exerc., vol. 13, no. 2, pp. 99-107, 2012.

[5] M. F. J. Syah and M. Yahya, "Burnout Among Teachers And Their Professional 
Development Case Study In Boyolali , Indonesia The Role Of External Agencies , Especially At The Local And Regional Level," Proceeding Int. Conf. Child-Friendly Educ., pp. 328-332, 2015.

[6] H. Jamil, "Teacher is Matter for Education Quality : A Transformation of Policy for Enhancing the Teaching Profession in Malaysia," vol. 16, no. 2, pp. 181-196, 2014.

[7] H. Harsono, S. Yulia Rosanti, and N. A. Abu Seman, "The Effectiveness of Posters as a Learning Media to Improve Student Learning Quality.," J. Soc. Sci. Res., no. Special Issue 5, pp. 757-763, 2018.

[8] A. Neghavati, “Core Skills Training in a Teacher Training Programme," Procedia Soc. Behav. Sci., vol. 232, no. April, pp. 617-622, 2016.

[9] A. Tjalla, "Potret Mutu Pendidikan Indonesia Ditinjau dari," Temu Ilm. Nas. Guru II, no. 3, pp. 1-22, 2005.

[10] D. Adhiningsih, "Pengaruh Persepsi Siswa Tentang Metode Mengajar Guru Dan Kemandirian Belajar Terhadap Prestasi Belajar Akuntansi Siswa Kelas X Program Keahlian Akuntansi Smk Batik Perbaik Purworejo Tahun Ajaran 2011/2012,” Kaji. Pendidik. Akunt. Indones., pp. 57-77, 2012.

[11] M. Sari, "Problematika Pembelajaran Sains Ditinjau Dari Aspek Guru," AL-Ta lim, vol. 20, no. 1, p. 346, 2013.

[12] I. K. Suartama, "Kualitas Pembelajaran Pada Mata Kuliah Media," J. Pendidik. dan Pengajaran, vol. 43, no. 3, pp. 253-262, 2010.

[13] L. Leonard, "Kompetensi tenaga pendidik di indonesia: Analisis dampak rendahnya," Form. J. Ilm. Pendidik. MIPA, vol. 5, no. 3, pp. 192-201, 2015.

[14] Muhammad Ali, "Pengembangan Media pembelajaran Interaktif Mata Kuliah Medan Elektromagnetik," J. Edukasi@Elektro, vol. 5, no. 1, pp. 11-18, 2009.

[15] Samtono, "Guru Sebagai Key Person Dalam Upaya Peningkatan Mutu Pendidikan Di Sekolah (Penelitian Pada Guru - Guru SMA Negeri 1 Salatiga) (Samtono)," Among Makarti, vol. 3, no. 6, 2010.

[16] E. Farahani, "Menumbuh Kembangkan Budaya Kewirausahaan Dalam Masyarakat," J. Chem. Inf. Model., vol. 53, no. 9, pp. 1689-1699, 2013.

[17] Yusutria, "Profesionalisme Guru dalam meningkatkan kualitas sumberdaya manusia," J. Curricula, vol. 2, no. 2, pp. 38-46, 2017.

[18] H. Hafiar, "Peningkatan Pendidikan dan Pengembangan Kompetensi Guru SMA Negeri 1 Katapang melalui Partisipasi dalam Publikasi Akademis di Media Massa," Dharmakarya, vol. 4, no. 2, pp. 88-92, 2015.

[19] O. Tarhan, "The State of In-Service Training of Teachers and Teacher Training in National Education Councils," Procedia - Soc. Behav. Sci., vol. 197, no. February, pp. 378-381, 2015.

[20] D. İşlek and G. A. Baskan, "The Reconstructions at Pre-service Teacher Training Systems in Turkey (1998-2012)," Procedia - Soc. Behav. Sci., vol. 116, pp. 46604664, 2014.

[21] Y. T. Sung, H. Y. Lee, J. M. Yang, and K. E. Chang, "The quality of experimental designs in mobile learning research: A systemic review and self-improvement tool," Educ. Res. Rev., vol. 28, no. May, p. 100279, 2019.

[22] K. J. Gerritsen-van Leeuwenkamp, D. Joosten-ten Brinke, and L. Kester, "Students' perceptions of assessment quality related to their learning approaches and learning outcomes," Stud. Educ. Eval., vol. 63, no. July 2018, pp. 72-82, 2019.

[23] B. Özler, L. C. H. Fernald, P. Kariger, C. McConnell, M. Neuman, and E. Fraga, "Combining pre-school teacher training with parenting education: A cluster- 
randomized controlled trial," J. Dev. Econ., vol. 133, no. April, pp. 448-467, 2018.

[24] J. W. Creswell, Educational research: Planning, conducting, and evaluating quantitative and qualitative research, vol. 4. 2012. 